\title{
Scope of algae as third generation biofuels
}

\section{Shuvashish Behera, Richa Singh, Richa Arora, Nilesh Kumar Sharma, Madhulika Shukla and Sachin Kumar*}

Biochemical Conversion Division, Sardar Swaran Singh National Institute of Renewable Energy, Kapurthala, Punjab, India

\section{Edited by:}

Antonio Trincone, Istituto di Chimica

Biomolecolare, Consiglio Nazionale

delle Ricerche, Italy

Reviewed by:

Franz Goecke, Institute of

Microbiology A.S.C.R, Czech Republic

Sankar Prasad Bhattacharya, Monash

University, Australia

Antonio Trincone, Istituto di Chimica

Biomolecolare, Consiglio Nazionale

delle Ricerche, Italy

${ }^{*}$ Correspondence:

Sachin Kumar, Biochemical

Conversion Division, Sardar Swaran

Singh National Institute of Renewable

Energy, Jalandhar-Kapurthala Road,

Wadala Kalan, Kapurthala 144601,

Punjab, India

e-mail: sachin.biotech@gmail.com
An initiative has been taken to develop different solid, liquid, and gaseous biofuels as the alternative energy resources. The current research and technology based on the third generation biofuels derived from algal biomass have been considered as the best alternative bioresource that avoids the disadvantages of first and second generation biofuels. Algal biomass has been investigated for the implementation of economic conversion processes producing different biofuels such as biodiesel, bioethanol, biogas, biohydrogen, and other valuable co-products. In the present review, the recent findings and advance developments in algal biomass for improved biofuel production have been explored. This review discusses about the importance of the algal cell contents, various strategies for product formation through various conversion technologies, and its future scope as an energy security.

Keywords: algae, microalgae, biofuels, bioethanol, biogas, biodiesel, biohydrogen

\section{INTRODUCTION}

The requirement of energy for the mankind is increasing day by day. The major source of energy is based on fossil fuels only. Thus, the scarcity of fossil fuels, rising price of petroleum based fuels, energy protection, and increased global warming resulted in focusing on renewable energy sources such as solar, wind, hydro, tidal, and biomass worldwide (Goldemberg and Guardabassi, 2009; Dragone et al., 2010; Rajkumar et al., 2014).

Different biomass from various sources like agricultural, forestry, and aquatic have been taken into consideration as the feedstocks for the production of several biofuels such as biodiesel (Boyce et al., 2008; Yanqun et al., 2008), bioethanol (Behera et al., 2014), biohydrogen (Marques et al., 2011), bio-oil (Shuping et al., 2010), and biogas (Hughes et al., 2012; Singh et al., 2014). However, the environmental impact raised from burning of fuels has a great impact on carbon cycle (carbon balance), which is related to the combustion of fossil fuels. Besides, exhaustion of different existing biomass without appropriate compensation resulted in huge biomass scarcity, emerging environmental problems such as deforestation and loss of biodiversity (Goldemberg, 2007; Li et al., 2008; Saqib et al., 2013).

Recently, researchers and entrepreneurs have focused their interest, especially on the algal biomass as the alternative feedstock for the production of biofuels. Moreover, algal biomass has no competition with agricultural food and feed production (Demirbas, 2007). The photosynthetic microorganisms like microalgae require mainly light, carbon dioxide, and some nutrients (nitrogen, phosphorus, and potassium) for its growth, and to produce large amount of lipids and carbohydrates, which can be further processed into different biofuels and other valuable coproducts (Brennan and Owende, 2010; Nigam and Singh, 2011).
Interestingly, the low content of hemicelluloses and about zero content of lignin in algal biomass results in an increased hydrolysis and/or fermentation efficiency (Saqib et al., 2013). Other than biofuels, algae have applications in human nutrition, animal feed, pollution control, biofertilizer, and waste water treatment (Thomas, 2002; Tamer et al., 2006; Crutzen et al., 2007; Hsueh et al., 2007; Choi et al., 2012). Therefore, the aim of the current review is to explore the scope of algae for the production of different biofuels and evaluation of its potential as an alternative feedstock.

\section{ALGAE: SOURCE OF BIOFUELS}

Generally, algae are a diverse group of prokaryotic and eukaryotic organisms ranging from unicellular genera such as Chlorella and diatoms to multicellular forms such as the giant kelp, a large brown alga that may grow up to $50 \mathrm{~m}$ in length (Li et al., 2008). Algae can either be autotrophic or heterotrophic. The autotrophic algae require only inorganic compounds such as $\mathrm{CO}_{2}$, salts, and a light energy source for their growth, while the heterotrophs are non-photosynthetic, which require an external source of organic compounds as well as nutrients as energy sources (Brennan and Owende, 2010). Microalgae are very small in sizes usually measured in micrometers, which normally grow in water bodies or ponds. Microalgae contain more lipids than macroalgae and have the faster growth in nature (Lee et al., 2014a). There are about more than 50,000 microalgal species out of which only about 30,000 species have been taken for the research study (Surendhiran and Vijay, 2012; Richmond and Qiang, 2013; Rajkumar et al., 2014). The short harvesting cycle of algae is the key advantage for its importance, which is better than other conventional crops having harvesting cycle of once or twice in a year (Chisti, 2007; Schenk 
et al., 2008). Therefore, the main focus has been carried out on algal biomass for its application in biofuel area.

There are several advantages of algal biomass for biofuels production: (a) ability to grow throughout the year, therefore, algal oil productivity is higher in comparison to the conventional oil seed crops; (b) higher tolerance to high carbon dioxide content; (c) the consumption rate of water is very less in algae cultivation; (d) no requirement of herbicides or pesticides in algal cultivation; (e) the growth potential of algal species is very high in comparison to others; (f) different sources of wastewater containing nutrients like nitrogen and phosphorus can be utilized for algal cultivation apart from providing any additional nutrient; and ( $\mathrm{g}$ ) the ability to grow under harsh conditions like saline, brackish water, coastal seawater, which does not affect any conventional agriculture (Spolaore et al., 2006; Dismukes et al., 2008; Dragone et al., 2010). However, there are several disadvantages of algal biomass as feedstock such as the higher cultivation cost as compared to conventional crops. Similarly, harvesting of algae require high energy input, which is approximately about $20-30 \%$ of the total cost of production. Several techniques such as centrifugation, flocculation, floatation, sedimentation, and filtration are usually used for harvesting and concentrating the algal biomass (Demirbas, 2010; Ho et al., 2011).

The algae can be converted into various types of renewable biofuels including bioethanol, biodiesel, biogas, photobiologically produced biohydrogen, and further processing for bio-oil and syngas production through liquefaction and gasification, respectively (Kraan, 2013). The conversion technologies for utilizing algal biomass to energy sources can be categorized into three different ways, i.e., biochemical, chemical, and thermochemical conversion and make an algal biorefinery, which has been depicted in Figure 1. The biofuel products derived from algal biomass using these conversion routes have been explored in detail in the subsequent sections.

\section{BIODIESEL PRODUCTION}

Biodiesel is a mixture of monoalkyl esters of long chain fatty acids [fatty acid methyl esters (FAME)], which can be obtained from different renewable lipid feedstocks and biomass. It can be directly used in different diesel engines (Clark and Deswarte, 2008; Demirbas, 2009). Studies to explore the microalgae as feedstock for the production of liquid fuels had been started for the mid-1980s. In order to solve the energy crisis, the extraction of lipids from diatoms was attempted by some German scientists during the period of World War-II (Cohen et al., 1995). The higher oil yield in algal biomass as compared to oil seed crops makes the possibility to convert into the biodiesel economically using different technologies. A comparative study between algal biomass and terrestrial plants for the production

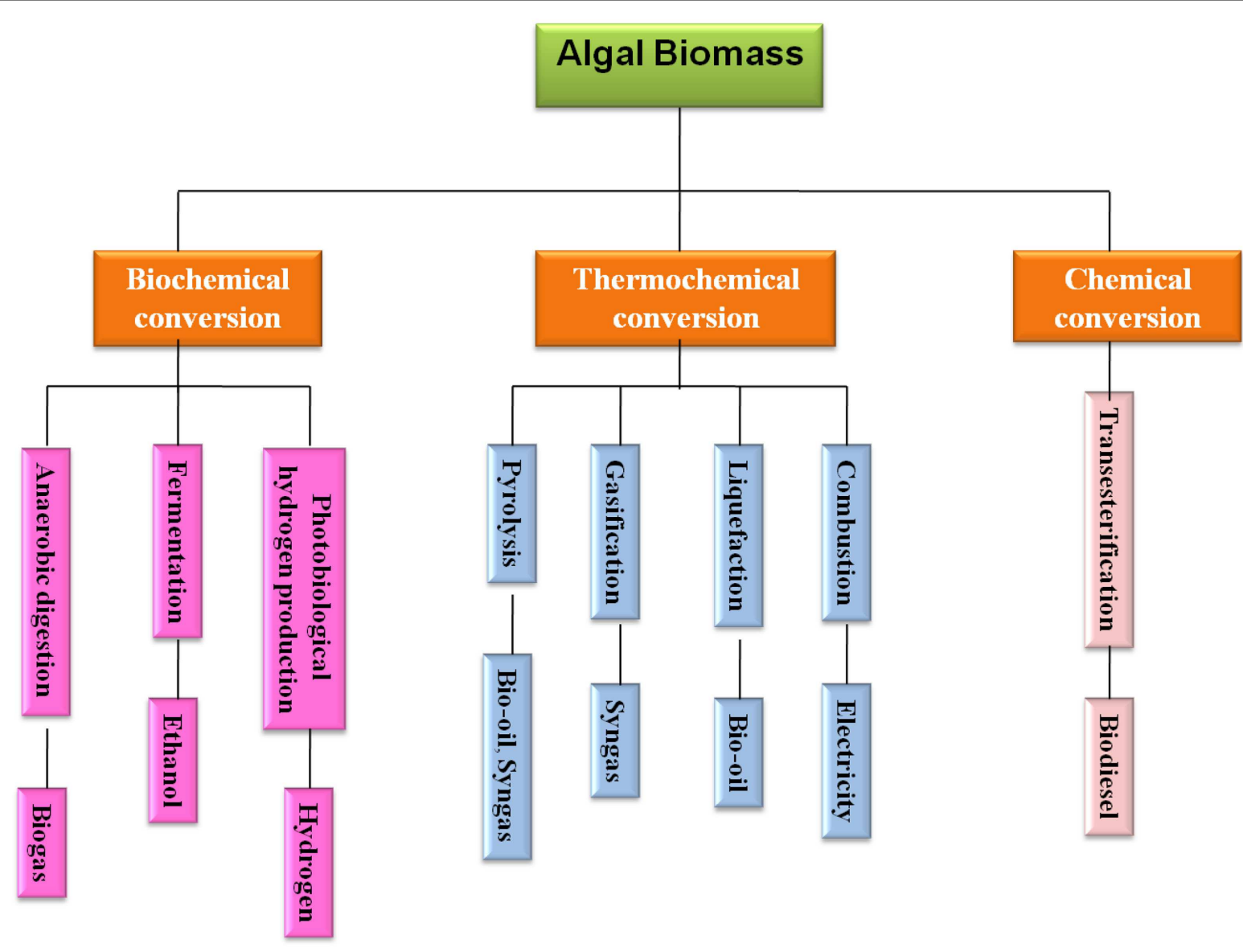

FIGURE 1 | Algal biomass conversion process for biofuel production. 
of biodiesel has been depicted in Table 1. The oil productivity (mass of oil produced per unit volume of the microalgal broth per day) depends on the algal growth rate and the biomass content of the species. The species of microalgae such as Kirchneriella lunaris, Ankistrodesmus fusiformis, Chlamydocapsa bacillus, and Ankistrodesmus falcatus with high levels of polyunsaturated FAME are generally preferred for the production of biodiesel (Nascimento et al., 2013). They commonly multiply their biomass with doubling time of $24 \mathrm{~h}$ during exponential growth. Oil content of microalgae is generally found to be very high, which exceed up to $80 \%$ by weight of its dry biomass. About 5,000-15,000 gal of biodiesel can be produced from algal biomass per acre per year, which reflects its potentiality (Spolaore et al., 2006; Chisti, 2007).

However, there are some standards such as International Biodiesel Standard for Vehicles (EN14214) and American Society for Testing and Materials (ASTM), which are required to comply with the algal based biodiesel on the physical and chemical properties for its acceptance as substitute to fossil fuels (Brennan and Owende, 2010). The higher degree of polyunsaturated fatty acids of algal oils as compared to vegetable oils make susceptible for oxidation in the storage and further limits its utilization (Chisti, 2007). Some researchers have reported the different advantages of the algal biomass for the biodiesel production due to its high biomass growth and oil productivity in comparison to best oil crops (Chisti, 2007; Hossain et al., 2008; Hu et al., 2008; Rosenberg et al., 2008; Schenk et al., 2008; Rodolfi et al., 2009; Mutanda et al., 2011).

Algal biodiesel production involves biomass harvesting, drying, oil extraction, and further transesterification of oil, which have been described as below.

\section{HARVESTING AND DRYING OF ALGAL BIOMASS}

Unicellular microalgae produce a cell wall containing lipids and fatty acids, which differ them from higher animals and plants. Harvesting of algal biomass and further drying is important prior to mechanical and solvent extraction for the recovery of oil. Macroalgae can be harvested using nets, which require less energy while microalgae can be harvested by some conventional processes, which include filtration (Rossignol et al., 1999) flocculation (Liu et al., 2013; Prochazkova et al., 2013), centrifugation (Heasman et al., 2008), foam fractionation (Csordas and Wang, 2004), sedimentation, froth floatation, and ultrasonic separation (Bosma et al., 2003). Selection of harvesting method depends on the type of algal species.

Drying is an important method to extend shelf-life of algal biomass before storage, which avoids post-harvest spoilage (Munir et al., 2013). Most of the efficient drying methods like spraydrying, drum-drying, freeze drying or lyophilization, and sundrying have been applied on microalgal biomass (Leach et al., 1998; Richmond, 2004; Williams and Laurens, 2010). Sun-drying is not considered as a very effective method due to presence of high water content in the biomass (Mata et al., 2010). However, Prakash et al. (2007) used simple solar drying device and succeed in drying Spirulina and Scenedesmus having $90 \%$ of moisture content. Widjaja et al. (2009) showed the effectiveness of drying temperature during lipid extraction of algal biomass, which affects both concentration of triglycerides and lipid yield. Further, all these processes possess safety and health issues (Singh and Gu, 2010).

\section{EXTRACTION OF OIL FROM ALGAL BIOMASS}

Unicellular microalgae produce a cell wall containing lipids and fatty acids, which differ them from higher animals and plants. In

Table 1 | Comparative study between algal biomass and terrestrial plants for biodiesel production

\begin{tabular}{|c|c|c|c|}
\hline Feedstock & Conditions & Biodiesel & Reference \\
\hline \multicolumn{4}{|l|}{ ALGAE } \\
\hline Spirulina platensis & $\begin{array}{l}\text { Reaction temperature } 55^{\circ} \mathrm{C}, 60 \% \text { catalyst concentration, } 1: 4 \text { algae biomass } \\
\text { to methanol ratio, } 450 \mathrm{rpm} \text { stirring intensity }\end{array}$ & $60 \mathrm{~g} / \mathrm{kg}$ lipid & Nautiyal et al. (2014) \\
\hline Nannochloropsis sp. & Oil extraction with n-hexane, acidic transesterification & $99 \mathrm{~g} / \mathrm{kg}$ lipid & Susilaningsih et al. (2009) \\
\hline \multirow[t]{2}{*}{ Scenedesmus sp. } & Alkaline $(\mathrm{NaOH})$, temperature of $70^{\circ} \mathrm{C}$ & $321.06 \mathrm{~g} / \mathrm{kg}$ lipid & Kim et al. (2014) \\
\hline & Acidic $\left(\mathrm{H}_{2} \mathrm{SO}_{4}\right)$ catalyst, temperature of $70^{\circ} \mathrm{C}$ & $282.23 \mathrm{~g} / \mathrm{kg}$ lipid & \\
\hline Nannochloropsis salina & $\begin{array}{l}\text { Freeze drying of biomass, extraction with chloroform-methanol (1:1 ratio), } \\
\text { alkali transesterification }\end{array}$ & $180.78 \mathrm{~g} / \mathrm{kg}$ lipid & Muthukumar et al. (2012) \\
\hline Chlorella marina & & $100 \mathrm{~g} / \mathrm{kg}$ lipid & \\
\hline \multicolumn{4}{|l|}{ TERRESTRIAL PLANTS } \\
\hline Madhuca indica & $\begin{array}{l}0.30-0.35(\mathrm{v} / \mathrm{v}) \text { methanol-to-oil ratio, } 1 \%(\mathrm{v} / \mathrm{v}) \mathrm{H}_{2} \mathrm{SO}_{4} \text { as acid catalyst, } 0.25 \\
(\mathrm{v} / \mathrm{v}) \text { methanol, } 0.7 \%(\mathrm{w} / \mathrm{v}) \mathrm{KOH} \text { as alkaline catalyst }\end{array}$ & $186.2 \mathrm{~g} / \mathrm{kg}$ lipid & Ghadge and Raheman (2005) \\
\hline \multirow[t]{2}{*}{ Pongamia pinnata } & Transesterification with methanol, $\mathrm{NaOH}$ as catalyst, temp. $60^{\circ} \mathrm{C}$ & $253 \mathrm{~g} / \mathrm{kg}$ lipid & Mamilla et al. (2011) \\
\hline & $\begin{array}{l}\text { Acid-catalyzed esterification by using } 0.5 \% \mathrm{H}_{2} \mathrm{SO}_{4} \text {, alkali-catalyzed } \\
\text { transesterification }\end{array}$ & $193.2 \mathrm{~g} / \mathrm{kg}$ lipid & Naik et al. (2008) \\
\hline Azadirachta indica & $\begin{array}{l}\text { Reaction time of } 60 \mathrm{~min}, 0.7 \% \mathrm{H}_{2} \mathrm{SO}_{4} \text { as acid catalyst, reaction } \\
\text { temperature of } 50^{\circ} \mathrm{C} \text {, and methanol: oil ratio of } 3: 1\end{array}$ & $170 \mathrm{~g} / \mathrm{kg}$ lipid & Awolu and Layokun (2013) \\
\hline Soybean & $\begin{array}{l}\text { Hydrotalcite as basic catalyst, methanol/oil molar ratio of } 20: 1 \text {, reaction } \\
\text { time of } 10 \mathrm{~h}\end{array}$ & $189.6 \mathrm{~g} / \mathrm{kg}$ lipid & Martin et al. (2013) \\
\hline
\end{tabular}


the literature, there are different methods of oil extraction from algae, such as mechanical and solvent extraction (Li et al., 2014). However, the extraction of lipids from microalgae is costly and energy intensive process.

\section{Mechanical oil extraction}

The oil from nuts and seeds is extracted mechanically using presses or expellers, which can also be used for microalgae. The algal biomass should be dried prior to this process. The cells are just broken down with a press to leach out the oil. About $75 \%$ of oil can be recovered through this method and no special skill is required (Munir et al., 2013). Topare et al. (2011) extracted oil through screw expeller by mechanical pressing (by piston) and osmotic shock method and recovered about $75 \%$ of oil from the algae. However, more extraction time is required as compared to other methods, which make the process unfavorable and less effective (Popoola and Yangomodou, 2006).

\section{Solvent based oil extraction}

Oil extraction using solvent usually recovers almost all the oil leaving only $0.5-0.7 \%$ residual oil in the biomass. Therefore, the solvent extraction method has been found to be suitable method rather than the mechanical extraction of oil and fats (Topare et al., 2011). Solvent extraction is another method of lipid extraction from microalgae, which involves two stage solvent extraction systems. The amount of lipid extracted from microalgal biomass and further yield of highest biodiesel depends mainly on the solvent used. Several organic solvents such as chloroform, hexane, cyclohexane, acetone, and benzene are used either solely or in mixed form (Afify et al., 2010). The solvent reacts on algal cells releasing oil, which is recovered from the aqueous medium. This occurs due to the nature of higher solubility of oil in organic solvents rather than water. Further, the oil can be separated from the solvent extract. The solvent can be recycled for next extraction. Out of different organic solvents, hexane is found to be most effective due to its low toxicity and cost (Rajvanshi and Sharma, 2012; Ryckebosch et al., 2012).

In case of using mixed solvents for oil extraction, a known quantity of the solvent mixture is used, for example, chloroform/methanol in the ratio $2: 1(\mathrm{v} / \mathrm{v})$ for $20 \mathrm{~min}$ using a shaker and followed by the addition of mixture, i.e., chloroform/water in the ratio of 1:1 (v/v) for $10 \mathrm{~min}$ (Shalaby, 2011). Similarly, Pratoomyot et al. (2005) extracted oil from different algal species using the solvent system chloroform/methanol in the ratio of 2:1 $(\mathrm{v} / \mathrm{v})$ and found different fatty acid content. Ryckebosch et al.
(2012) optimized an analytical procedure and found chloroform/methanol in the ratio $1: 1$ as the best solvent mixture for the extraction of total lipids. Similarly, Lee et al. (1998) extracted lipid from the green alga Botryococcus braunii using different solvent system and obtained the maximum lipid content with chloroform/methanol in the ratio of 2:1. Hossain et al., 2008 used hexane/ether in the ratio 1:1 (v/v) for oil extraction and allowed to settle for $24 \mathrm{~h}$. Using a two-step process, Fajardo et al. (2007) reported about $80 \%$ of lipid recovery using ethanol and hexane in the two steps for the extraction and purification of lipids. Therefore, a selection of a most suitable solvent system is required for the maximum extraction of oil for an economically viable process.

Lee et al. (2009) compared the performance of various disruption methods, including autoclaving, bead-beating, microwaves, sonication, and using $10 \% \mathrm{NaCl}$ solution in the extraction of Botryococcus sp., Chlorella vulgaris, and Scenedesmus sp, using a mixture of chloroform and methanol (1:1).

\section{TRANSESTERIFICATION}

This is a process to convert algal oil to biodiesel, which involves multiple steps of reactions between triglycerides or fatty acids and alcohol. Different alcohols such as ethanol, butanol, methanol, propanol, and amyl alcohol can be used for this reaction. However, ethanol and methanol are used frequently for the commercial development due to its low cost and its physical and chemical advantages (Bisen et al., 2010; Surendhiran and Vijay, 2012). The reaction can be performed in the presence of an inorganic catalyst (acids and alkalies) or lipase enzyme. In this method, about $3 \mathrm{~mol}$ of alcohol are required for each mole of triglyceride to produce $3 \mathrm{~mol}$ of methyl esters (biodiesel) and $1 \mathrm{~mol}$ of glycerol (by-product) (Meher et al., 2006; Chisti, 2007; Sharma and Singh, 2009; Surendhiran and Vijay, 2012; Stergiou et al., 2013) (Figure 2). Glycerol is denser than biodiesel and can be periodically or continuously removed from the reactor in order to drive the equilibrium reaction. The presence of methanol, the co-solvent that keeps glycerol and soap suspended in the oil, is known to cause engine failure (Munir et al., 2013). Thus, the biodiesel is recovered by repeated washing with water to remove glycerol and methanol (Chisti, 2007).

The reaction rate is very slow by using the acid catalysts for the conversion of triglycerides to methyl esters, whereas the alkalicatalyzed transesterification reaction has been reported to be 4000 times faster than the acid-catalyzed reaction (Mazubert et al., 2013). Sodium and potassium hydroxides are the two commercial alkali catalysts used at a concentration of about $1 \%$ of oil.

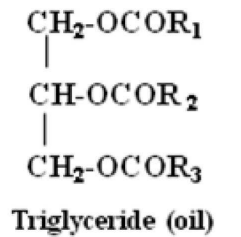

$3 \mathrm{HOCH}_{3}$

Methanol (alcohol)

Triglyceride (oil)
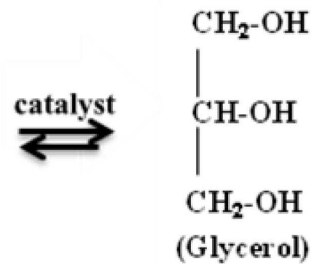

$\mathrm{R}_{\mathbf{1}}-\mathrm{COOCH}_{3}$

$\mathrm{R}_{2}-\mathrm{COOCH}_{3}$

$\mathrm{R}_{3}-\mathrm{COOCH}_{3}$

Methyl Esters (Biodiesel)

FIGURE 2 | Transesterification of oil to biodiesel. $R_{1-3}$ are hydrocarbon groups. 
However, sodium methoxide has become the better catalyst rather than sodium hydroxide (Singh et al., 2006).

Kim et al. (2014) used Scenedesmus sp. for the biodiesel production through acid and alkali transesterification process. They reported $55.07 \pm 2.18 \%$, based on lipid by wt of biodiesel conversion using $\mathrm{NaOH}$ as an alkaline catalyst than using $\mathrm{H}_{2} \mathrm{SO}_{4}$ as $48.41 \pm 0.21 \%$ of biodiesel production. In comparison to acid and alkalies, lipases as biocatalyst have different advantages as the catalysts due to its versatility, substrate selectivity, regioselectivity, enantioselectivity, and high catalytic activity at ambient temperature and pressure (Knezevic et al., 2004). It is not possible by some lipases to hydrolyze ester bonds at secondary positions, while some other group of enzymes hydrolyzes both primary and secondary esters. Another group of lipases exhibits fatty acids selectivity, and allow to cleave ester bonds at particular type of fatty acids. Luo et al. (2006) cloned the lipase gene lipB68 and expressed in Escherichia coli BL21 and further used it as a catalyst for biodiesel production. LipB68 could catalyze the transesterification reaction and produce biodiesel with a yield of $92 \%$ after $12 \mathrm{~h}$, at a temperature of $20^{\circ} \mathrm{C}$. The activity of the lipase enzyme with such a low temperature could provide substantial savings in energy consumption. However, it is rarely used due to its high cost (Sharma et al., 2001).

\section{Extractive transesterification}

It involves several steps to produce biodiesel such as drying, cell disruption, oils extraction, transesterification, and biodiesel refining (Hidalgo et al., 2013). The main problems are related with the high water content of the biomass (over 80\%), which overall increases the cost of whole process.

\section{In situ transesterification}

This method skips the oil extraction step. The alcohol acts as an extraction solvent and an esterification reagent as well, which enhances the porosity of the cell membrane. Yields found are higher than via the conventional route, and waste is also reduced. Industrial biodiesel production involves release of extraction solvent, which contributes to the production of atmospheric smog and to global warming. Thus, simplification of the esterification processes can reduce the disadvantages of this attractive bio-based fuel. The single-step methods can be attractive solutions to reduce chemical and energy consumption in the overall biodiesel production process (Patil et al., 2012). A comparison of direct and extractive transesterification is given in Table 2.

\section{BIOETHANOL PRODUCTION}

Several researchers have been reported bioethanol production from certain species of algae, which produce high levels of carbohydrates as reserve polymers. Owing to the presence of low lignin and hemicelluloses content in algae in comparison to lignocellulosic biomass, the algal biomass have been considered more suitable for the bioethanol production (Chen et al., 2013). Recently, attempts have been made (for the bioethanol production) through the fermentation process using algae as the feedstocks to make it as an alternative to conventional crops such as corn and soyabean (Singh et al., 2011; Nguyen and Vu, 2012; Chaudhary et al., 2014). A comparative study of algal biomass and terrestrial plants for the production of bioethanol has been given in Table 3. There are
Table 2 | Comparison of extractive transesterification and in situ methods (Haas and Wagner, 2011).

\section{SI. no. Extractive transesterification In situ transesterification}

\begin{tabular}{lll}
\hline 1 & Low heating value & Heating value is high \\
2 & Product yield is low & Higher product yield \\
3 & $\begin{array}{l}\text { Process is complex and time } \\
\text { taking }\end{array}$ & $\begin{array}{l}\text { Quick and simple operation } \\
\text { process }\end{array}$ \\
4 & Lipid loss during process & $\begin{array}{l}\text { Avoided potential lipid loss } \\
\text { Reduced waste water pollutants }\end{array}$ \\
6 & $\begin{array}{l}\text { Waste water pollutes the } \\
\text { environment }\end{array}$ & $\begin{array}{l}\text { Roduction cost is high } \\
\text { Pbsence of harvesting and } \\
\text { dewatering lowers the cost }\end{array}$ \\
\end{tabular}

different micro and macroalgae such as Chlorococcum sp., Prymnesium parvum, Gelidium amansii, Gracilaria sp., Laminaria sp., Sargassum sp., and Spirogyra sp., which have been used for the bioethanol production (Eshaq et al., 2011; Rajkumar et al., 2014). These algae usually require light, nutrients, and carbon dioxide, to produce high levels of polysaccharides such as starch and cellulose. These polysaccharides can be extracted to fermentable sugars through hydrolysis and further fermentation to bioethanol and separated through distillation as shown in Figure 3.

\section{PRE-TREATMENT AND SACCHARIFICATION}

It has been reported that, the cell wall of some species of green algae like Spirogyra and Chlorococcum contain high level of polysaccharides. Microalgae such as C. vulgaris contains about $37 \%$ of starch on dry weight basis, which is the best source for bioethanol with 65\% conversion efficiency (Eshaq et al., 2010; Lam and Lee, 2012). Such polysaccharide based biomass requires additional processing like pre-treatment and saccharification before fermentation (Harun et al., 2010). Saccharification and fermentation can also be carried out simultaneously using an amylase enzyme producing strain for the production of ethanol in a single step. Bioethanol from microalgae can be produced through the process, which is similar to the first generation technologies involving corn based feedstocks. However, there is limited literature available on the fermentation process of microalgae biomass for the production of bioethanol (Schenk et al., 2008; John et al., 2011).

The pre-treatment is an important process, which facilitates accessibility of biomass to enzymes to release the monosaccharides. Acid pre-treatment is widely used for the conversion of polymers present in the cell wall to simple forms. The energy consumption in the pre-treatment is very low and also it is an efficient process (Harun and Danquah, 2011a,b). Yazdani et al. (2011) found $7 \%(\mathrm{w} / \mathrm{w}) \mathrm{H}_{2} \mathrm{SO}_{4}$ as the promising concentration for the pre-treatment of the brown macroalgae Nizimuddinia zanardini to obtain high yield of sugars without formation of any inhibitors. Candra and Sarinah (2011) studied the bioethanol production using red seaweed Eucheuma cottonii through acid hydrolysis. In this study, $5 \% \mathrm{H}_{2} \mathrm{SO}_{4}$ concentration was used for $2 \mathrm{~h}$ at $100^{\circ} \mathrm{C}$, which yielded $15.8 \mathrm{~g} / \mathrm{L}$ of sugars. However, there are other alternatives to chemical hydrolysis such as enzymatic digestion and gamma radiation to make it more sustainable (Chen et al., 2012; Yoon et al., 2012; Schneider et al., 2013). 
Table 3 | Comparative study between algal biomass and terrestrial plants for bioethanol production.

\begin{tabular}{|c|c|c|c|}
\hline Feedstock & Conditions & Bioethanol & Reference \\
\hline \multicolumn{4}{|l|}{ ALGAE } \\
\hline Chlorococcum infusionum & Alkaline pre-treatment, temp. $120^{\circ} \mathrm{C}$, S. cerevisiae & $260 \mathrm{~g}$ ethanol/kg algae & Harun et al. (2011) \\
\hline Spirogyra & $\begin{array}{l}\text { Alkaline pre-treatment, synthetic media growth, saccharification } \\
\text { of biomass by Aspergillus niger, fermentation by S. cerevisiae }\end{array}$ & $80 \mathrm{~g}$ ethanol/kg algae & Eshaq et al. (2010) \\
\hline Chlorococcum humicola & Acid pre-treatment, temp. $160^{\circ} \mathrm{C}$, S. cerevisiae & $\begin{array}{l}520 \mathrm{~g} \text { ethanol/kg } \\
\text { microalgae }\end{array}$ & Harun and Danquah (2011a) \\
\hline \multicolumn{4}{|l|}{ TERRESTRIAL PLANTS } \\
\hline Madhuca latifolia & $\begin{array}{l}\text { Strain Zymomonas mobilis MTCC 92, immobilized in Luffa } \\
\text { cylindrical sponge disks, temp. } 30^{\circ} \mathrm{C}\end{array}$ & $\begin{array}{l}251.1 \pm 0.012 \mathrm{~g} \text { ethanol } / \mathrm{kg} \\
\text { flowers }\end{array}$ & Behera et al. (2011) \\
\hline Manihot esculenta & $\begin{array}{l}\text { Enzyme termamyl and amyloglucosidase, } 1 \mathrm{~N} \mathrm{HCl}, \\
\text { Saccharomyces cerevisiae, ca-alginate immobilization }\end{array}$ & $\begin{array}{l}189 \pm 3.1 \mathrm{~g} \text { ethanol } / \mathrm{kg} \text { flour } \\
\text { cassava }\end{array}$ & Behera et al. (2014) \\
\hline Sugarcane bagasse & $\begin{array}{l}\text { Acid }\left(\mathrm{H}_{2} \mathrm{SO}_{4}\right) \text { hydrolysis, Kluyveromyces sp. IIPE } 453 \text {, } \\
\text { Fermentation at } 50^{\circ} \mathrm{C}\end{array}$ & $165 \mathrm{~g}$ ethanol/kg bagasse & Kumar et al., 2014 \\
\hline Rice straw & $\begin{array}{l}\text { Cellulase, } \beta \text {-glucosidase, solid state fermentation, strain } \\
\text { Trichoderma reesei RUT C30, and Aspergillus niger MTCC } 7956\end{array}$ & $\begin{array}{l}93 \mathrm{~g} \text { ethanol } / \mathrm{kg} \text { pretreated } \\
\text { rice straw }\end{array}$ & Sukumaran et al. (2008) \\
\hline
\end{tabular}

Similar to starch, there are certain polymers such as alginate, mannitol, and fucoidan present in the cell wall of various algae, which requires additional processing like pre-treatment and saccharification before fermentation. Another form of storage carbohydrate found in various brown seaweeds and microalgae is laminarin, which can be hydrolyzed by $\beta$-1,3-glucanases or laminarinases (Kumagai and Ojima, 2010). Laminarinases can be categorized into two groups such as exo- and endo-glucanases based on the mode of hydrolysis, which usually produces glucose and smaller oligosaccharides as the end product. Both the enzymes are necessary for the complete digestion of laminarin polymer (Lee et al., 2014b).

Markou et al. (2013) saccharified the biomass of Spirulina (Arthrospira platensis), fermented the hydrolyzate and obtained the maximum ethanol yield of 16.32 and $16.27 \%$ (gethanol $/ \mathrm{g}_{\text {biomass }}$ ) produced after pre-treatment with $0.5 \mathrm{~N} \mathrm{HNO}_{3}$ and $\mathrm{H}_{2} \mathrm{SO}_{4}$, respectively. Yanagisawa et al. (2011) investigated the content of polysaccharide materials present in three types of seaweeds such as sea lettuce (Ulva pertusa), chigaiso (Alaria crassifolia), and agar weed (Gelidium elegans). These seaweeds contain no lignin, which is a positive signal for the hydrolysis of polysaccharides without any pre-treatment. Singh and Trivedi (2013) used Spirogyra biomass for the production of bioethanol using Saccharomyces cerevisiae and Zymomonas mobilis. In a method, they followed acid pre-treatment of algal biomass and further saccharified using $\alpha$-amylase producing Aspergillus niger. In another method, they directly saccharified the biomass without any pre-treatment. The direct saccharification process resulted in $2 \%(\mathrm{w} / \mathrm{w})$ more alcohol in comparison to pretreated and saccharified algal biomass. This study revealed that the pre-treatment with different chemicals are not required in case of Spyrogyra, which reflects its economic importance for the production of ethanol. Also, cellulase enzyme has been used for the saccharification of algal biomass containing cellulose. However, this enzyme system is more expensive than amylases and glucoamylases, and doses required for effective cellulose saccharification are usually very high. Trivedi et al. (2013) applied different cellulases on green alga Ulva for saccharification and found highest conversion efficiency of biomass into reducing sugars by using cellulase 22119 rather than viscozyme L, cellulase 22086 and 22128. In this experiment, they found a maximum yield of sugar $206.82 \pm 14.96 \mathrm{mg} / \mathrm{g}$ with $2 \%$ (v/v) enzyme loading for $36 \mathrm{~h}$ at a temperature of $45^{\circ} \mathrm{C}$.

\section{FERMENTATION}

There are different groups of microorganisms like yeast, bacteria, and fungi, which can be used for the fermentation of the pretreated and saccharified algal biomass under anaerobic process for the production of bioethanol (Nguyen and Vu, 2012). Nowadays, S. cerevisiae and Z. mobilis have been considered as the bioethanol fermenting microorganisms. However, fermentation of mannitol, a polymer present in certain algae is not possible in anaerobic condition using these well known microorganisms and requires supply of oxygen during fermentation, which is possible only by Zymobacter palmae (Horn et al., 2000).

Certain marine red algae contain agar, a polymer of galactose and galactopyranose, which can be used for the production of bioethanol (Yoon et al., 2010). The biomass of red algae can be depolymerized into different monomeric sugars like glucose and galactose. In addition to mannitol and glucose, brown seaweeds contain about $14 \%$ of extra carbohydrates in the form of alginate (Wargacki et al., 2012). Horn et al. (2000) reported the presence of alginate, laminaran, mannitol, fucoidan, and cellulose in some brown seaweeds, which are good source of sugars. They fermented brown seaweed extract having mannitol using bacteria $Z$. palmae and obtained an ethanol yield of about $0.38 \mathrm{~g}$ ethanol $/ \mathrm{g}$ mannitol.

In the literature, there are many advantages supporting microalgae as the promising substrate for bioethanol production. Hon-Nami (2006) used Chlamydomonas perigranulata algal culture and obtained different by-products such as ethanol and butanediol. Similarly, Yanagisawa et al. (2011) obtained glucose 


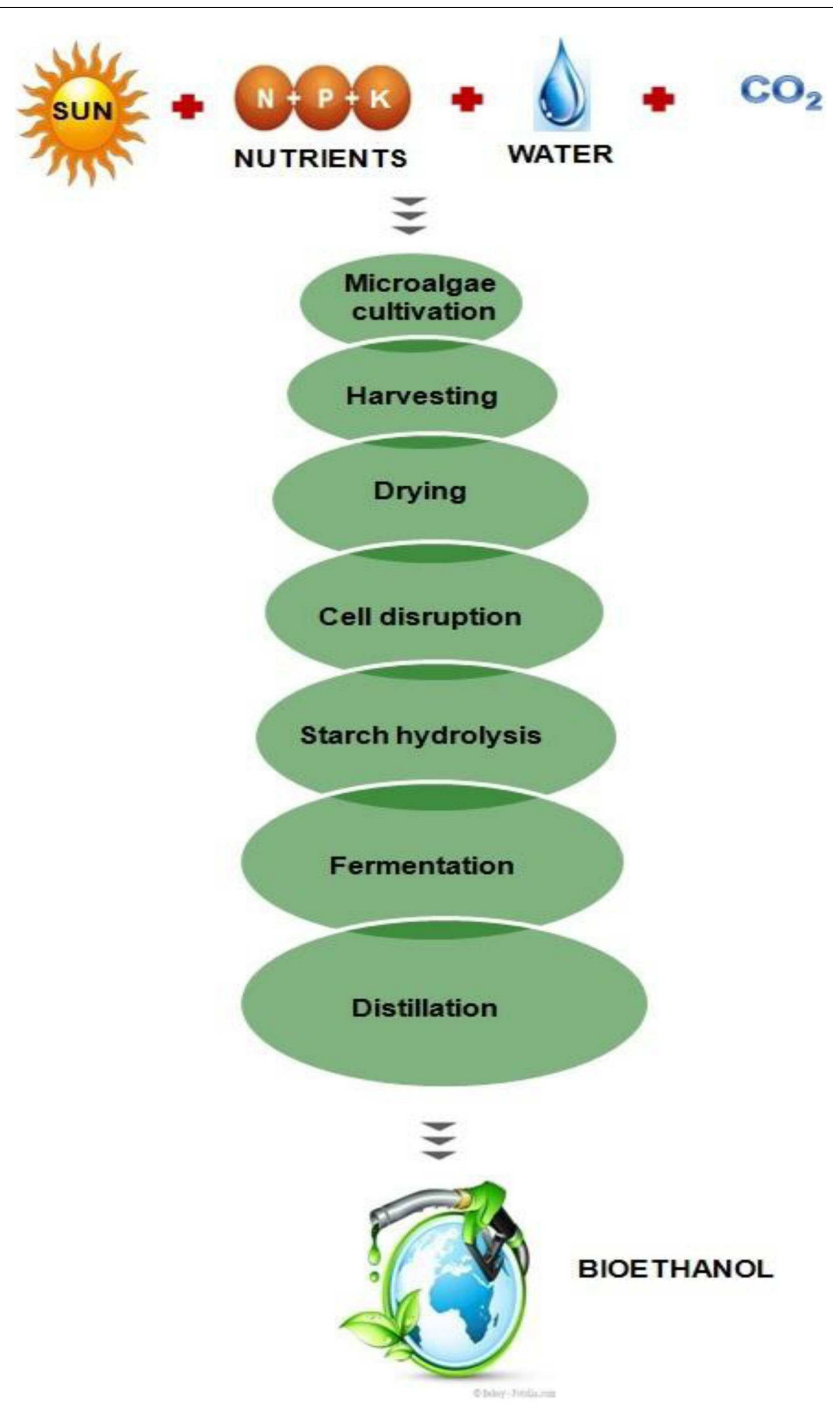

FIGURE 3 | Process for bioethanol production from microalgae.

and galactose through the saccharification of agar weed (red seaweed) containing glucan and galactan and obtained $5.5 \%$ of ethanol concentration through fermentation using $S$. cerevisiae IAM 4178. Harun et al. (2010) obtained 60\% more ethanol in case of lipid extracted microalgal biomass rather than intact algal biomass of Chlorococcum sp. This shows the importance of algal biomass for the production of both biodiesel and bioethanol.

\section{BIOGAS PRODUCTION}

Recently, biogas production from algae through anaerobic digestion has received a remarkable attention due to the presence of high polysaccharides (agar, alginate, carrageenan, laminaran, and mannitol) with zero lignin and low cellulose content. Mostly, seaweeds are considered as the excellent feedstock for the production of biogas. Several workers have demonstrated the fermentation of various species of algae like Scenedesmus, Spirulina, Euglena, and Ulva for biogas production (Samson and Leduy, 1986; Yen and Brune, 2007; Ras et al., 2011; Zhong et al., 2012; Saqib et al., 2013).
The production of biogas using algal biomass in comparison to some terrestrial plants is shown in Table 4.

Biogas is produced through the anaerobic transformation of organic matter present in the biodegradable feedstock such as marine algae, which releases certain gases like methane, carbon dioxide, and traces of hydrogen sulfide. The anaerobic conversion process involves basically four main steps. In the first step, the insoluble organic material and higher molecular mass compounds such as lipids, carbohydrates, and proteins are hydrolyzed into soluble organic material with the help of enzyme released by some obligate anaerobes such as Clostridia and Streptococci. The second step is called as acidogenesis, which releases volatile fatty acids (VFAs) and alcohols through the conversion of soluble organics with the involvement of enzymes secreted by the acidogenic bacteria. Further, these VFAs and alcohols are converted into acetic acid and hydrogen using acetogenic bacteria through the process of acetogenesis, which finally metabolize to methane and carbon dioxide by the methanogens (Cantrell et al., 2008; Vergara-Fernandez et al., 2008; Brennan and Owende, 2010; Romagnoli et al., 2011).

Sangeetha et al. (2011) reported the anaerobic digestion of green alga Chaetomorpha litorea with generation of $80.5 \mathrm{~L}$ of biogas $/ \mathrm{kg}$ of dry biomass under $299 \mathrm{psi}$ pressure. Vergara-Fernandez et al. (2008) evaluated digestion of the marine algae Macrocystis pyrifera and Durvillaea antarctica marine algae in a two-phase anaerobic digestion system and reported similar biogas productions of $180.4( \pm 1.5) \mathrm{mL} / \mathrm{g}$ dry algae/day with a methane concentration around $65 \%$. However, in case of algae blend, same methane content was observed with low biogas yield. Mussgnug et al. (2010) reported biogas production from some selected green algal species like Chlamydomonas reinhardtii and Scenedesmus obliquus and obtained 587 and $287 \mathrm{~mL}$ biogas/g of volatile solids, respectively. Further, there are few studies, which have been conducted with microalgae showing the effect of different pretreatment like thermal, ultrasound, and microwave for the high production of biogas (Gonzalez-Fernandez et al., 2012a,b; Passos et al., 2013).

However, there are different factors, which limit the biogas production such as requirement of larger land area, infrastructure, and heat for the digesters (Collet et al., 2011; Jones and Mayfield, 2012). The proteins present in algal cells increases the ammonium production resulting in low carbon to nitrogen ratio, which affects biogas production through the inhibition of growth of anaerobic microorganisms. Also, anaerobic microorganisms are inhibited by the sodium ions. Therefore, it is recommended to use the salt tolerating microorganisms for the anaerobic digestion of algal biomass (Yen and Brune, 2007; Brennan and Owende, 2010; Jones and Mayfield, 2012).

\section{BIOHYDROGEN PRODUCTION}

Recently, algal biohydrogen production has been considered to be a common commodity to be used as the gaseous fuels or electricity generation. Biohydrogen can be produced through different processes like biophotolysis and photo fermentation (Shaishav et al., 2013). Biohydrogen production using algal biomass is comparative to that of terrestrial plants (Table 5). Park et al. (2011) found Gelidium amansii (red alga) as the potential source of biomass for the production of biohydrogen through anaerobic 
Table 4 | Comparative study between algal biomass and terrestrial plants for biogas production.

\begin{tabular}{|c|c|c|c|}
\hline Feedstock & Conditions & Biogas & Reference \\
\hline \multicolumn{4}{|l|}{ ALGAE } \\
\hline Blue algae & $\mathrm{pH}-6.8$, microcystin (MC) biodegradation & $189.89 \mathrm{~mL} / \mathrm{g}$ of VS & Yuan et al. (2011) \\
\hline Chlamydomonas reinhardtii & Drying as the pre-treatment, batch fermentation, temp. $38^{\circ} \mathrm{C}$ & $587 \mathrm{~mL} / \mathrm{g}$ of $\mathrm{VS}$ & Mussgnug et al. (2010) \\
\hline Scenedesmus obliquus & & $287 \mathrm{~mL} / \mathrm{g}$ of $\mathrm{VS}$ & \\
\hline Ulva sp. & Batch reactor, Co-digestion with bovine slurry, temp. $35^{\circ} \mathrm{C}$ & $191 \mathrm{~mL} / \mathrm{g}$ of VS & Vanegas and Bartlett (2013) \\
\hline Laminaria digitata & & $246 \mathrm{~mL} / \mathrm{g}$ of $\mathrm{VS}$ & \\
\hline Saccorhiza polyschides & & $255 \mathrm{~mL} / \mathrm{g}$ of $\mathrm{VS}$ & \\
\hline Saccharina latissima & & $235 \mathrm{~mL} / \mathrm{g}$ of $\mathrm{VS}$ & \\
\hline \multicolumn{4}{|l|}{ TERRESTRIAL PLANTS } \\
\hline Banana stem & Pre-treatment: $6 \% \mathrm{NaOH}$ in $55^{\circ} \mathrm{C}$ for $54 \mathrm{~h} .37 \pm 1^{\circ} \mathrm{C}$ for 40 days, batch & $357.9 \mathrm{~mL} / \mathrm{g}$ of $\mathrm{VS}$ & Zhang (2013) \\
\hline Saline creeping wild ryegrass & $35^{\circ} \mathrm{C}$ for 33 days, batch & $251 \mathrm{~mL} / \mathrm{g}$ of $\mathrm{VS}$ & Zheng (2009) \\
\hline Rice straw & $\begin{array}{l}\text { Pre-treatment: ammonia conc. } 4 \% \text { and moisture content } 70 \% \text {, temp. } \\
35 \pm 2{ }^{\circ} \mathrm{C}, 65 \text { days, } 120 \mathrm{rpm} \text {, batch }\end{array}$ & $341.35 \mathrm{~mL} / \mathrm{g}$ of VS & Yuan (2014) \\
\hline Date palm tree wastes & Pre-treatment: alkaline, particle size $2-5 \mathrm{~mm}$, temp. $40^{\circ} \mathrm{C}$ & $342.2 \mathrm{~mL} / \mathrm{g}$ of VS & Al-Juhaimi (2014) \\
\hline
\end{tabular}

Table 5 | Comparative study between algal biomass and terrestrial plants for biohydrogen production.

\begin{tabular}{|c|c|c|c|}
\hline Feedstock & Conditions & Biohydrogen & Reference \\
\hline \multicolumn{4}{|l|}{ ALGAE } \\
\hline Gelidium amansii & Hydrolysis at $150^{\circ} \mathrm{C}$ & $53.5 \mathrm{~mL}$ of $\mathrm{H}_{2} / \mathrm{g}$ of dry algae & Park et al. (2011) \\
\hline Laminaria japonica & $\begin{array}{l}\text { Mesophilic condition }\left(35 \pm 1^{\circ} \mathrm{C}\right), \mathrm{pH} \text { of } 7.5 \text {, anaerobic sequencing } \\
\text { batch reactor, hydraulic retention time (HRT) of } 6 \text { days }\end{array}$ & $71.4 \mathrm{~mL} \mathrm{H} / \mathrm{g}$ of dry algae & Shi et al. (2011) \\
\hline \multicolumn{4}{|l|}{ TERRESTRIAL PLANTS } \\
\hline Bagasse & Strain Klebsiella oxytoca HP1, temp. $37.5^{\circ} \mathrm{C}, \mathrm{pH}-7$ & $107.8 \pm 7.5 \mathrm{~mL} \mathrm{H} / \mathrm{g}$ bagasse & Wu et al. (2010) \\
\hline Corn stalk & Temp. $55^{\circ} \mathrm{C}, \mathrm{pH}-7.4$ & $61.4 \mathrm{~mL} / \mathrm{g}$ of cornstalk & Cheng and Liu (2011) \\
\hline Pretreated wheat straw & Strain Caldicellulosiruptor saccharolyticus, Temp. $70^{\circ} \mathrm{C}, \mathrm{pH}-7.2$ & $44.7 \mathrm{~mL} / \mathrm{g}$ of dry wheat straw & Ivanova et al. (2009) \\
\hline Wheat straw & $\begin{array}{l}\text { Acid pre-treatment, simultaneous saccharification and } \\
\text { fermentation (SSF) }\end{array}$ & $141 \mathrm{~mL} / \mathrm{g}$ VS & Nasirian et al. (2011) \\
\hline
\end{tabular}

fermentation. Nevertheless, they found $53.5 \mathrm{~mL}$ of $\mathrm{H}_{2}$ from $1 \mathrm{~g}$ of dry algae with a hydrogen production rate of $0.518 \mathrm{~L} \mathrm{H}_{2} / \mathrm{g}$ VSS/day. The authors found an inhibitor, namely, 5-hydroxymethylfurfural (HMF) produced through the acid hydrolysis of G. amansii that decreases about $50 \%$ of hydrogen production due to the inhibition. Thus, optimization of the pre-treatment method is an important step to maximize biohydrogen production, which will be useful for the future direction (Park et al., 2011; Shi et al., 2011). Saleem et al. (2012) reduced the lag time for hydrogen production using microalgae Chlamydomonas reinhardtii by the use of optical fiber as an internal light source. In this study, the maximum rate of hydrogen production in the presence of exogenic glucose and optical fiber was reported to be $6 \mathrm{~mL} / \mathrm{L}$ culture $/ \mathrm{h}$, which is higher than other reported values.

Some of microalgae like blue green algae have glycogen instead of starch in their cells. This is an exception, which involves oxidation of ferrodoxin by the hydrogenase enzyme activity for the production of hydrogen in anaerobic condition. However, another function of this enzyme is to be involved in the detachment of electrons. Therefore, different researchers have focused for the identification of these enzyme activities having interactions with ferrodoxin and the other metabolic functions for microalgal photobiohydrogen production. They are also involved with the change of these interactions genetically to enhance the biohydrogen production (Gavrilescu and Chisti, 2005; Hankamer et al., 2007; Wecker et al., 2011; Yacoby et al., 2011; Rajkumar et al., 2014).

\section{BIO-OIL AND SYNGAS PRODUCTION}

Bio-oil is formed in the liquid phase from algal biomass in anaerobic condition at high temperature. The composition of bio-oil varies according to different feedstocks and processing conditions, which is called as pyrolysis (Iliopoulou et al., 2007; Yanqun et al., 2008). There are several parameters such as water, ash content, biomass composition, pyrolysis temperature, and vapor residence time, which affect the bio-oil productivity (Fahmi et al., 2008). However, due to the presence of water, oxygen content, unsaturated and phenolic moieties, crude bio-oil cannot be used as fuel. Therefore, certain treatments are required to improve its quality 
(Bae et al., 2011). Bio-oils can be processed for power generation with the help of external combustion through steam and organic rankine cycles, and stirling engines. However, power can also be generated through internal combustion using diesel and gas-turbine engines (Chiaramonti et al., 2007). In literature, there are limited studies on algae pyrolysis compared to lignocellulosic biomass. Although, high yields of bio-oil occur through fluidizedbed fast pyrolysis processes, there are several other pyrolysis modes, which have been introduced to overcome their inherent disadvantages of a high level of carrier gas flow and excessive energy inputs (Oyedun et al., 2012). Demirbas (2006) investigated suitability of the microalgal biomass for bio-oil production and found the superior quality than the wood. Porphy and Farid (2012) produced bio-oil from pyrolysis of algae (Nannochloropsis sp.) at $300^{\circ} \mathrm{C}$ after lipid extraction, which composed of $50 \mathrm{wt} \%$ acetone, $30 \mathrm{wt} \%$ methyl ethyl ketone, and $19 \mathrm{wt} \%$ aromatics such as pyrazine and pyrrole. Similarly, Choi et al. (2014) carried out pyrolysis study on a species of brown algae Saccharina japonica at a temperature of $450^{\circ} \mathrm{C}$ and obtained about $47 \%$ of bio-oil yield.

Gasification is usually performed at high temperatures (800$1000^{\circ} \mathrm{C}$ ), which converts biomass into the combustible gas mixture through partial oxidation process, called syngas or producer gas. Syngas is a mixture of different gases like $\mathrm{CO}, \mathrm{CO}_{2}, \mathrm{CH}_{4}, \mathrm{H}_{2}$, and $\mathrm{N}_{2}$, which can also be produced through normal gasification of woody biomass. In this process, biomass reacts with oxygen and water (steam) to generate syngas. It is a low calorific gas, which can be utilized in the gas turbines or used directly as fuel. Different variety of biomass feedstocks can be utilized for the production of energy through the gasification process, which is an added advantage (Carvalho et al., 2006; Prins et al., 2006; Lv et al., 2007).

\section{CONCLUSION AND FUTURE PERSPECTIVES}

Recently, it is a challenge for finding different alternative resources, which can replace fossil fuels. Due to presence of several advantages in algal biofuels like low land requirement for biomass production and high oil content with high productivity, it has been considered as the best resource, which can replace the liquid petroleum fuel. However, one of its bottlenecks is the low biomass production, which is a barrier for industrial production. Also, another disadvantage includes harvesting of biomass, which possesses high energy inputs. For an economic process development in comparison to others, a cost-effective and energy efficient harvesting methods are required with low energy input. Producing low-cost microalgal biofuels requires better biomass harvesting methods, high biomass production with high oil productivity through genetic modification, which will be the future of algal biology. Therefore, use of the standard algal harvesting technique, biorefinery concept, advances in photobioreactor design and other downstream technologies will further reduce the cost of algal biofuel production, which will be a competitive resource in the near future.

\section{ACKNOWLEDGMENTS}

The authors are thankful to Prof. Y. K. Yadav, Director, NIRE, Kapurthala for his consistent support to write this review paper. The authors greatly acknowledge the Ministry of New and
Renewable Energy, New Delhi, Govt. of India, for providing funds to carry out research work.

\section{REFERENCES}

Afify, A. M. M., Shanab, S. M., and Shalaby, E. A. (2010). Enhancement of biodiesel production from different species of algae. Grasas y Aceites 61, 416-422. doi:10.3989/gya.021610

Al-Juhaimi, F. Y. (2014). Biogas production through the anaerobic digestion of date palm tree wastes - process optimization. Bioresources 9, 3323-3333. doi:10.15376/biores.9.2

Awolu, O. O., and Layokun, S. K. (2013). Optimization of two-step transesterification production of biodiesel from neem (Azadirachta indica) oil. Int. J. Energy Environ. 4, 39. doi:10.1186/2251-6832-4-39

Bae, Y. J., Ryu, C., Jeon, J. K., Park, J., Suh, D. J., Suh, Y. W., et al. (2011). The characteristics of bio-oil produced from the pyrolysis of three marine macroalgae. Bioresour. Technol. 102, 3512-3520. doi:10.1016/j.biortech.2010.11.023

Behera, S., Mohanty, R. C., and Ray, R. C. (2011). Ethanol production from mahula (Madhuca latifolia L.) flowers using free and immobilized (in Luffa cylindrical L. sponge discs) cells of Zymomonas mobilis MTCC 92. Ann. Microbiol. 61, 469-474. doi:10.1007/s13213-010-0160-y

Behera, S., Mohanty, R. C., and Ray, R. C. (2014). Batch ethanol production from cassava (Manihot esculenta Crantz.) flour using Saccharomyces cerevisiae cells immobilized in calcium alginate. Ann. Microbiol. doi:10.1007/s13213-0140918-8

Bisen, P. S., Sanodiya, B. S., Thakur, G. S., Baghel, R. K., and Prasad, G. B. K. S. (2010). Biodiesel production with special emphasis on lipase-catalyzed transesterification. Biotechnol. Lett. 32, 1019-1030. doi:10.1007/s10529-010-0275-z

Bosma, R., Van Spronsen, W. A., Tramper, J., and Wijffels, R. H. (2003). Ultrasound a new s separation technique to harvest microalgae. J. Appl. Phycol. 15, 143-153. doi:10.1023/A:1023807011027

Boyce, A. N., Chowd-Hury, P., and Naqiuddin, M. (2008). Biodiesel fuel production from algae as renewable energy. Am. J. Biochem. Biotechnol. 4, 250-254. doi:10.3844/ajbbsp.2008.250.254

Brennan, L., and Owende, P. (2010). Biofuels from microalgae-a review of technologies for production, processing, and extractions of biofuels and co-products. Renew. Sustain. Energ. Rev. 14, 557-577. doi:10.1016/j.rser.2009.10.009

Candra, K. P., and Sarinah, S. (2011). Study on bioethanol production using red seaweed Eucheuma cottonii from Bontang sea water. J. Coastal Dev. 15, 45-50. doi:10.4172/1410-5217.10000328

Cantrell, K. B., Ducey, T., Ro, K. S., and Hunt, P. G. (2008). Livestock waste-tobioenergy generation opportunities. Bioresour. Technol. 99, 7941-7953. doi:10. 1016/j.biortech.2008.02.061

Carvalho, A. P., Meireles, L. A., and Malcata, F. X. (2006). Microalgal reactors: a review of enclosed system designs and performances. Biotechnol. Prog. 22, 1490-1506. doi:10.1002/bp060065r

Chaudhary, L., Pradhan, P., Soni, N., Singh, P., and Tiwari, A. (2014). Algae as a feedstock for bioethanol production: new entrance in biofuel world. Int. J. Chem. Technol. Res. 6, 1381-1389.

Chen, C. Y., Zhao, X. Q., Yen, H. W., Ho, S. H., Cheng, C. L., Bai, F., et al. (2013). Microalgae-based carbohydrates for biofuel production. Biochem. Eng. J. 78, 1-10. doi:10.1016/j.bej.2013.03.006

Chen, R., Yue, Z., Deitz, L., Liu, Y., and Liao, W. (2012). Use of an algal hydrolysate to improve enzymatic hydrolysis of lignocellulose. Bioresour. Technol. 108, 149-154. doi:10.1016/j.biortech.2011.12.143

Cheng, X. Y., and Liu, C. Z. (2011). Hydrogen production via thermophilic fermentation of cornstalk by Clostridium thermocellum. Energy Fuel 25, 1714-1720. doi:10.1021/ef2000344

Chiaramonti, D., Oasmaa, A., and Solantausta, Y. (2007). Power generation using fast pyrolysis liquids from biomass. Renew. Sustain. Energ. Rev. 11, 1056-1086. doi:10.1016/j.rser.2005.07.008

Chisti, Y. (2007). Biodiesel from microalgae. Biotechnol. Adv. 25, 294-306. doi:10. 1016/j.biotechadv.2007.02.001

Choi, J. H., Woo, H. C., and Suh, D. J. (2014). Pyrolysis of seaweeds for bio-oil and bio-char production. Chem. Eng. Trans. 37, 121-126. doi:10.1016/j.biortech. 2014.09.068

Choi, W., Han, J., Lee, C., Song, C., Kim, J., Seo, Y., et al. (2012). Bioethanol production from Ulva pertusa kjellman by high-temperature liquefaction. Chem. Biochem. Eng. 26, 15-21. 
Clark, J., and Deswarte, F. (2008). Introduction to Chemicals from Biomass. Wiley series in renewable resources. Hoboken: John Wiley \& Sons.

Cohen, Z., Norman, H. A., and Heimer, Y. M. (1995). Microalgae as a source of X-3 fatty acids. World Rev. Nutr. Diet. 77, 1-31.

Collet, P., Helias, A., Lardon, L., Ras, M., Goy, R. A., and Steyer, J. P. (2011). Lifecycle assessment of microalgae culture coupled to biogas production. Bioresour. Technol. 102, 207-214. doi:10.1016/j.biortech.2010.06.154

Crutzen, P. J., Mosier, A. R., Smith, K. A., and Winiwarter, W. (2007). N 2 O release from agro-biofuel production negates global warming reduction by replacing fossil fuels. Atmos. Chem. Phys. 7, 11191-11205. doi:10.5194/acpd-7-11191-2007

Csordas, A., and Wang, J. (2004). An integrated photobioreactor and foam fractionation unit for growth and harvest of Chaetoceros sp in open systems. Aquac. Eng. 30, 15-30. doi:10.1016/j.aquaeng.2003.07.001

Demirbas, A. (2006). Oily products from mosses and algae via pyrolysis. Energy Source 28, 933-940. doi:10.1080/009083190910389

Demirbas, A. (2007). Progress and recent trends in biofuels. Prog. Energy Combust. Sci. 33, 1-18. doi:10.1016/j.pecs.2006.06.001

Demirbas, A. (2009). Progress and recent trends in biodiesel fuels. Energy Convers. Manag. 50, 14-34. doi:10.1016/j.enconman.2008.09.001

Demirbas, A. (2010). Use of algae as biofuel sources. Energy Convers. Manag. 51, 2738-2749. doi:10.1016/j.enconman.2010.06.010

Dismukes, G. C., Carrieri, D., Bennette, N., Ananyev, G. M., and Posewitz, M. C. (2008). Aquatic phototrophs: efficient alternatives to land-based crops for biofuels. Curr. Opin. Biotechnol. 19, 235-240. doi:10.1016/j.copbio.2008.05.007

Dragone, G., Fernandes, B., Vicente, A. A., and Teixeira, J. A. (2010). "Third generation biofuels from microalgae," in Current Research, Technology and Education Topics in Applied Microbiology and Microbial Biotechnology, ed. A. Mendez-Vilas (Madrid: Formatex), 1315-1366

Eshaq, F. S., Ali, M. N., and Mohd, M. K. (2010). Spirogyra biomass a renewable source for biofuel (bioethanol) production. Int. J. Eng. Sci. Technol. 2, 7045-7054.

Eshaq, F. S., Ali, M. N., and Mohd, M. K. (2011). Production of bioethanol from next generation feed-stock alga Spirogyra species. Int. J. Eng. Sci. Technol. 3, 1749-1755.

Fahmi, R., Bridgwater, A. V., Donnison, I., and Yates, N. (2008). The effect of lignin and inorganic species in biomass on pyrolysis oil yield, quality and stability. Fuel 87, 1230-1240. doi:10.1016/j.fuel.2007.07.026

Fajardo, A. R., Cerdan, L. E., Medina, A. R., Fernandez, F. G. A., Moreno, P. A. G., and Grima, E. M. (2007). Lipid extraction from the microalga Phaeodactylum tricornutum. Eur. J. Lipid Sci. Technol. 109, 120-126. doi:10.1002/ejlt.200600216

Gavrilescu, M., and Chisti, Y. (2005). Biotechnology - a sustainable alternative for chemical industry. Biotechnol. Adv. 23, 471-499. doi:10.1016/j.biotechadv.2005. 03.004

Ghadge, S. V., and Raheman, H. (2005). Biodiesel production from mahua (Madhuca indica) oil having high free fatty acids. Biomass Bioenergy 28, 601-605. doi:10.1016/j.biombioe.2004.11.009

Goldemberg, J. (2007). Ethanol for a sustainable energy future. Science 315, 808-810. doi:10.1126/science. 1137013

Goldemberg, J., and Guardabassi, P. (2009). Are biofuels a feasible option? Energy Policy 37, 10-14. doi:10.1016/j.enpol.2008.08.031

Gonzalez-Fernandez, C., Sialve, B., Bernet, N., and Steyer, J. P. (2012a). Comparison of ultrasound and thermal pretreatment of Scenedesmus biomass on methane production. Bioresour. Technol. 110, 610-616. doi:10.1016/j.biortech. 2012.01.043

Gonzalez-Fernandez, C., Sialve, B., Bernet, N., and Steyer, J. P. (2012b). Thermal pretreatment to improve methane production of Scenedesmus biomass. Biomass Energy 40, 105-111. doi:10.1016/j.biombioe.2012.02.008

Haas, M. I., and Wagner, K. (2011). Simplifying biodiesel production: the direct or in situ transesterification of algal biomass. Eur. J. Lipid Sci. Technol. 113, 1219-1229. doi:10.1002/ejlt.201100106

Hankamer, B., Lehr, F., Rupprecht, J., Mussgnug, J. H., Posten, C., and Kruse, O. (2007). Photosynthetic biomass and $\mathrm{H}_{2}$ production by green algae: from bioengineering to bioreactor scale up. Physiol. Plant. 131, 10-21. doi:10.1111/j.13993054.2007.00924.x

Harun, R., and Danquah, M. K. (2011a). Influence of acid pre-treatment on microalgal biomass for bioethanol production. Process Biochem. 46, 304-309. doi:10.1016/j.procbio.2010.08.027

Harun, R., and Danquah, M. K. (2011b). Enzymatic hydrolysis of microalgae biomass for bioethanol production. Chem. Eng. J. 168, 1079-1084. doi:10.1016/j. cej.2011.01.088
Harun, R., Danquah, M. K., and Forde-Gareth, M. (2010). Microalgal biomass as a fermentation feedstock for bioethanol production. J. Chem. Technol. Biotechnol. 85, 199-203. doi:10.1002/jctb.2287

Harun, R., Jason, W. S. Y., Cherrington, T., and Danquah, M. K. (2011). Exploring alkaline pretreatment of microalgal biomass for bioethanol production. Appl. Energy 88, 3464-3467. doi:10.1016/j.apenergy.2010.10.048

Heasman, M., Diemar, J. O., Connor, W., Shushames, T., Foulkes, L., and Nell, J. (2008). Development of extended shelf-life microalgae concentrate diets harvested by centrifugation for bivalve molluscs - a summary. Aquac. Res. 31, 637-659. doi:10.1046/j.1365-2109.2000.318492.x

Hidalgo, P., Toro, C., Ciudad, G., and Navia, R. (2013). Advances in direct transesterification microalgal biomass for biodiesel production. Rev. Environ. Sci. Biotechnol. 12, 179-199. doi:10.1007/s11157-013-9308-0

Ho, S. H., Chen, C. Y., Lee, D. J., and Chang, J. S. (2011). Perspectives on microalgal $\mathrm{Co}_{2}$-emission mitigation systems-a review. Biotechnol. Adv. 29, 189-198. doi:10.1016/j.biotechadv.2010.11.001

Hon-Nami, K. (2006). A unique feature of hydrogen recovery in endogenous starch to alcohol fermentation of the marine microalga Chlamydomonas perigranulata. Appl. Biochem. Biotechnol. 131, 808-828. doi:10.1385/ABAB:131:1:808

Horn, H. J., Aasen, I. M., and Østgaard, M. (2000). Production of ethanol from mannitol by Zymobacter palmae. J. Ind. Microbiol. Biotechnol. 24, 51-57. doi:10.1038/sj.jim.2900771

Hossain, A. B. M. S., Salleh, A., Boyce, A. N., Chowd-Hury, P., and Naqiuddin, M. (2008). Biodiesel fuel production from algae as renewable energy. Am. J. Biochem. Biotechnol. 4, 250-254. doi:10.3844/ajbbsp.2008.250.254

Hsueh, H. T., Chu, H., and Yu, S. T. (2007). A batch study on the bio-fixation of carbon dioxide in the absorbed solution from a chemical wet scrubber by hot spring and marine algae. Chemosphere 66, 878-886. doi:10.1016/j.chemosphere. 2006.06.022

Hu, Q., Sommerfeld, M., Jarvis, E., Ghirardi, M., Posewitz, M., Seibert, M., et al. (2008). Microalgal triacylglycerols as feedstocks for biofuels production: perspectives and advances. Plant J. 54, 621-639. doi:10.1111/j.1365-313X.2008.03492.x

Hughes, A. D., Kelly, M. S., Black, K. D., and Stanley, M. S. (2012). Biogas from macroalgae: is it time to revisit the idea? Biotechnol. Biofuels 5, 1-7. doi:10.1186/1754-6834-5-86

Iliopoulou, E. F., Antonakou, E. V., Karakoulia, S. A., Vasalos, I. A., Lappas, A. A., and Triantafyllidis, K. S. (2007). Catalytic conversion of biomass pyrolysis products by mesoporous materials: effect of steam stability and acidity of Al-MCM-41 catalysts. Chem. Eng. J. 134, 51-57. doi:10.1016/j.cej.2007.03.066

Ivanova, G., Rakhely, G., and Kovacs, K. (2009). Thermophilic biohydrogen production from energy plants by Caldicellulosiruptor saccharolyticus and comparison with related studies. Int. J. Hydrogen Energy 34, 3659-3670. doi:10.1016/j. ijhydene.2009.02.082

John, R. P., Anisha, G. S., Nampoothiri, K. M., and Pandey, A. (2011). Micro and macroalgal biomass: a renewable source for bioethanol. Bioresour. Technol. 102, 186-193. doi:10.1016/j.biortech.2010.06.139

Jones, C. S., and Mayfield, S. P. (2012). Algae biofuels: versatility for the future of bioenergy. Curr. Opin. Biotechnol.23, 346-351. doi:10.1016/j.copbio.2011.10.013

Kim, G. V., Choi, W. Y., Kang, D. H., Lee, S. Y., and Lee, H. Y. (2014). Enhancement of biodiesel production from marine alga, Scenedesmus sp. through in situ transesterification process associated with acidic catalyst. BioMed. Res. Int. 2014:391542 doi:10.1155/2014/391542

Knezevic, Z. D., Siler-Marinkovic, S. S., and Mojovic, L. V. (2004). Immobilized lipases as practical catalysts. Acta Period. Technol. 35, 151-164. doi:10.2298/ APT0435151K

Kraan, S. (2013). Mass cultivation of carbohydrate rich microalgae, a possible solution for sustainable biofuel production. Mitig. Adapt. Strateg. Glob. Change. 18, 27-46. doi:10.1007/s11027-010-9275-5

Kumagai, Y., and Ojima, T. (2010). Isolation and characterization of two types of $\beta$-1,3-glucanases from the common sea hare Aplysia kurodai. Comp. Biochem. Physiol. Biochem. Mol. Biol. 155, 138-144. doi:10.1016/j.cbpb.2009.10. 013

Kumar, S., Dheeran, P., Singh, S. P., Mishra, I. M., and Adhikari, D. K. (2014). Bioprocessing for bagasse hydrolysate for ethanol and xylitol production using thermotolerant yeast. Biprocess Biosyst. Eng. 38, 39-47. doi:10.1007/s00449-0141241-2

Lam, M. K., and Lee, K. T. (2012). Microalgae biofuels: a critical review of issues, problems and the way forward. Biotechnol. Adv. 30, 630-690. doi:10.1016/j. biotechadv.2011.11.008 
Leach, G., Oliveira, G., and Morais, R. (1998). Spray-drying of Dunaliella salina to produce a b-carotene rich powder. J. Ind. Microbiol. Biotechnol. 20, 82-85. doi:10.1038/sj.jim.2900485

Lee, A., Lewis, D., and Ashman, P. (2009). Microbial flocculation, a potentially lowcost harvesting technique for marine microalgae for the production of biodiesel. J. Appl. Phycol. 21, 559-567. doi:10.1007/s10811-008-9391-8

Lee, K., Eisterhold, M. L., Rindi, F., Palanisami, S., and Nam, P. K. (2014a). Isolation and screening of microalgae from natural habitats in the Midwestern United States of America for biomass and biodiesel sources. J. Nat. Sci. Biol. Med. 5, 333-339. doi:10.4103/0976-9668.136178

Lee, K. C., Takamitsu, A., Ibrahim, D., Kosugi, A., Prawitwong, P., Lan, D., et al. (2014b). Purification and characterization of a thermostable laminarinase from Penicillium rolfsii c3-2(1) IBRL. Bioresource 9, 1072-1084. doi:10.15376/biores. 9.1

Lee, S. J., Yoon, B. D., and Oh, H. M. (1998). Rapid method for the determination of lipid from the green alga Botryococcus braunii. Biotechnol. Tech. 12, 553-556. doi:10.1023/A:1008811716448

Li, Y., Horsman, M., Wu, N., Lan, C. Q., and Dubois-Calero, N. (2008). Biofuels from microalgae. Biotechnol. Progr. 24, 815-820. doi:10.1021/bp070371k

Li, Y., Naghdi, F. G., Garg, G., Adarme-Vega, T. C., Thurecht, K. J., Ghafor, W. A., et al. (2014). A comparative study: the impact of different lipid extraction methods on current microalgal lipid research. Microb. Cell Fact. 13, 1-9. doi:10.1186/1475-2859-13-14

Liu, J., Zhu, Y., Tao, Y., Zhang, Y., Li, A., Li, T., et al. (2013). Freshwater microalgae harvested via flocculation induced by $\mathrm{pH}$ decrease. Biotechnol. Biofuels 6, 98 . doi:10.1186/1754-6834-6-98

Luo, Y., Zheng, Y., Jiang, Z., Ma, Y., and Wei, D. (2006). A novel psychrophilic lipase from Pseudomonas fluorescens with unique property in chiral resolution and biodiesel production via transesterification. Appl. Microbiol. Biotechnol. 73, 349-355. doi:10.1007/s00253-006-0478-3

Lv, P., Yuan, Z., Wu, C., Ma, L., Chen, Y., and Tsubaki, N. (2007). Biosyngas production from biomass catalytic gasification. Energy. Convers. Manag. 48, 1132-1139. doi:10.1016/j.enconman.2006.10.014

Mamilla, V. R., Mallikarjun, M. V., and Rao, G. L. N. (2011). Preparation of biodiesel from Karanja oil. Int. J. Energy Eng. 1, 94-100. doi:10.5963/IJEE0102008

Markou, G., Angelidaki, I., Nerantzis, E., and Georgakakis, D. (2013). Bioethanol production by carbohydrate-enriched biomass of Arthrospira (Spirulina) platensis. Energies 6, 3937-3950. doi:10.3390/en6083937

Marques, A. E., Barbosa, A. T., Jotta, J., Coelho, M. C., Tamagnini, P., and Gouveia, L. (2011). Biohydrogen production by Anabaena sp. PCC 7120 wild-type and mutants under different conditions: light, nickel, propane, carbon dioxide and nitrogen. Biomass Bioenergy 35, 4426-4434. doi:10.1016/j.biombioe.2011. 08.014

Martin, M., Pires, R. F., Alves, M. J., Hori, C. E., Reis, M. H. M., and Cardoso, V. L. (2013). Transesterification of soybean oil for biodiesel production using hydrotalcite as basic catalyst. Chem. Eng. Trans. 32, 817-822. doi:10.3303/CET1332137

Mata, T. M., Martins, A., and Caetano, N. S. (2010). Microalgae for biodiesel production and other applications: a review. Ren. Sust. Energy. Rev. 14, 217-232. doi:10.1016/j.rser.2009.07.020

Mazubert, A., Poux, M., and Aubin, J. (2013). Intensified processes for FAME production from waste cooking oil: a technological review. Chem. Eng. J. 233, 201-223. doi:10.1016/j.cej.2013.07.063

Meher, L. C., Vidya, S. D., and Naik, S. N. (2006). Technical aspects of biodiesel production by transesterification - a review. Renew. Sustain. Energ. Rev. 10, 248-268. doi:10.1016/j.biotechadv.2014.10.003

Munir, N., Sharif, N., Naz, S., Saleem, F., and Manzoor, F. (2013). Harvesting and processing of microalgae biomass fractions for biodiesel production (a review). Sci. Tech. Dev. 32, 235-243.

Mussgnug, J. H., Klassen, V., Schluter, A., and Kruse, O. (2010). Microalgae as substrates for fermentative biogas production in a combined biorefinery concept. $J$. Biotechnol. 150, 51-56. doi:10.1016/j.jbiotec.2010.07.030

Mutanda, T., Ramesh, D., Karthikeyan, S., Kumari, S., Anandraj, A., and Bux, F. (2011). Bioprospecting for hyper-lipid producing microalgal strains for sustainable biofuel production. Bioresour. Technol. 102, 57-70. doi:10.1016/j.biortech. 2010.06.077

Muthukumar, A., Elayaraja, S., Ajithkumar, T. T., Kumaresan, S., and Balasubramanian, T. (2012). Biodiesel production from marine microalgae Chlorella marina and Nannochloropsis salina. J. Petrol. Technol Altern. Fuels 3, 58-62. doi:10.5897/JPTAF12.010
Naik, M., Meher, L. C., Waik, S. N., and Das, L. M. (2008). Production of biodiesel from high free fatty acid Karanja (Pongamia pinnata) oil. Biomass Bioenergy 32, 354-357. doi:10.1016/j.biombioe.2007.10.006

Nascimento, I. A., Marques, S. S. I., Cabanelas, I. T. D., Pereira, S. A., Druzian, J. I., de Souza, C. O., etal. (2013). Screening microalgae strains for biodiesel production: lipid productivity and estimation of fuel quality based on fatty acids profiles as selective criteria. Bioenerg. Res. 6, 1-13. doi:10.1007/s12155-012-9222-2

Nasirian, N., Almassi, M., Minaei, S., and Widmann, R. (2011). Development of a method for biohydrogen production from wheat straw by dark fermentation. Int. J. Hydrogen Energy 36, 411-420. doi:10.1016/j.ijhydene.2010.09.073

Nautiyal, P., Subramanian, K. A., and Dastidar, M. G. (2014). Kinetic and thermodynamic studies on biodiesel production from Spirulina platensis algae biomass using single stage extraction-transesterification process. Fuel 135, 228-234. doi:10.1016/j.fuel.2014.06.063

Nguyen, T. H. M., and Vu, V. H. (2012). Bioethanol production from marine algae biomass: prospect and troubles. J. Viet. Env. 3, 25-29. doi:10.13141/jve.vol3.nol

Nigam, P. S., and Singh, A. (2011). Production of liquid biofuels from renewable resources. Prog. Energy Combust. Sci. 37, 52-68. doi:10.1016/j.pecs.2010.01.003

Oyedun, A. O., Lam, K. L., Gebreegziabher, T., Lee, H. K. M., and Hui, C. W. (2012). Optimisation of operating parameters in multi-stage pyrolysis. Chem. Engg. Trans. 29, 655-660. doi:10.3303/CET1229110

Park, J. H., Yoon, J. J., Park, H. D., Kim, Y. J., Lim, D. J., and Kim, S. H. (2011). Feasibility of biohydrogen production from Gelidium amansii. Int. J. Hydrogen Energy 36, 13997-14003. doi:10.1016/j.ijhydene.2011.04.003

Passos, F., Sole, M., Garcia, J., and Ferrer, I. (2013). Biogas production from microalgae grown in wastewater: effect of microwave pretreatment. Appl. Energy 108, 168-175. doi:10.1016/j.watres.2013.10.013

Patil, P. D., Gude, V. G., Mannarswamy, A., Cooke, P., Nirmalakhandan, N., Lammers, P., et al. (2012). Comparison of direct transesterification of algal biomass under supercritical methanol and microwave irradiation conditions. Fuel 97, 822-831. doi:10.1016/j.fuel.2012.02.037

Popoola, T. O. S., and Yangomodou, O. D. (2006). Extraction, properties and utilization potentials of cassava seed oil. Biotechnology 5, 38-41. doi:10.3923/biotech. 2006.38.41

Porphy, S. J., and Farid, M. M. (2012). Feasibility study for production of biofuel and chemicals from marine microalgae Nannochloropsis sp. based on basic mass and energy analysis. ISRN Renew. Energ. 2012:156824. doi:10.5402/2012/156824

Prakash, J., Pushparaj, B., Carlozzi, P., Torzillo, G., Montaini, E., and Materassi, R. (2007). Microalgal biomass drying by a simple solar device. Int. J. Solar Energy 18, 303-311. doi:10.1080/01425919708914325

Pratoomyot, J., Srivilas, P., and Noiraksar, T. (2005). Fatty acids composition of 10 microalgal species. J. Sci. Technol. 27, 1179-1187.

Prins, M. J., Ptasinski, K. J., and Janssen, F. J. J. G. (2006). More efficient biomass gasification via torrefaction. Energy 31, 3458-3470. doi:10.1016/j.energy.2006. 03.008

Prochazkova, G., Safarik, I., and Branyik, T. (2013). Harvesting microalgae with microwave synthesized magnetic microparticles. Bioresour. Technol. 130, 472-477. doi:10.1016/j.biortech.2012.12.060

Rajkumar, R., Yaakob, Z., and Takriff, M. S. (2014). Potential of the micro and macro algae for biofuel production: a brief review. Bioresour. 9, 1606-1633. doi:10.15376/biores.9.1

Rajvanshi, S., and Sharma, M. P. (2012). Microalgae: a potential source of biodiesel. J. Sustain. Bioenergy Syst. 2, 49-59. doi:10.4236/jsbs.2012.23008

Ras, M., Lardon, L., Bruno, S., Bernet, N., and Steyer, J. P. (2011). Experimental study on a coupled process of production and anaerobic digestion of Chlorella vulgaris. Bioresour. Technol. 102, 200-206. doi:10.1016/j.biortech.2010.06.146

Richmond, A. (2004). Handbook of Microalgal Culture: Biotechnology and Applied Phycology. Osney Mead, Oxford: Blackwell Science Ltd.

Richmond, A., and Qiang, H. (2013). Handbook of Microalgal Culture: Applied Phycology and Biotechnology, Second Edn. Hoboken, NJ: Wiley-Blackwell.

Rodolfi, L., Zittelli, G. C., Bassi, N., Padovani, G., Biondi, N., Bonini, G., et al. (2009). Microalgae for oil: strain selection, induction of lipid synthesis and outdoor mass cultivation in a low-cost photobioreactor. Biotechnol. Bioeng. 102, 100-112. doi:10.1002/bit.22033

Romagnoli, F., Blumberga, D., and Gigli, E. (2011). Biogas from marine macroalgae: a new environmental technology-life cycle inventory for a further LCA. Environ. Climate Technol. 4, 97-108. doi:10.2478/v10145-010-0024-5

Rosenberg, J. N., Oyler, G. A., Wilkinson, L., and Betenbaugh, M. J. (2008). A green light for engineered algae: redirecting metabolism to fuel a biotechnology 
revolution. Curr. Opin. Biotechnol. 19, 430-436. doi:10.1016/j.copbio.2008.07. 008

Rossignol, N., Vandanjon, L., Jaoue, P., and Quemeneur, F. (1999). Membrane technology for the continuous separation of microalgae/culture medium: compared performances of cross-flow microfiltration and ultrafiltration. Aquac. Eng. 20, 191-208. doi:10.1016/S0144-8609(99)00018-7

Ryckebosch, E., Muylaert, K., and Foubert, I. (2012). Optimization of an analytical procedure for extraction of lipids from microalgae. J. Am. Oil Chem. Soc. 89, 189-198. doi:10.1007/s11746-011-1903-z

Saleem, M., Chakrabarti, M. H., Raman, A. A. A., Hasan, D. B., Daud, W. M. A. W., and Mustafa, A. (2012). Hydrogen production by Chlamydomonas reinhardtii in a two-stage process with and without illumination at alkaline $\mathrm{pH}$. Int. J. Hydrogen Energy 37, 4930-4934. doi:10.1016/j.ijhydene.2011.12.115

Samson, R., and Leduy, A. (1986). Detailed study of anaerobic digestion of Spirulina maxima algal biomass. Biotechnol. Bioeng. 28, 1014-1023. doi:10.1002/bit. 260280712

Sangeetha, P., Babu, S., and Rangasamy, R. (2011). Potential of green alga Chaetomorpha litorea (Harvey) for biogas production. Int. J. Curr. Sci. 1, 24-29.

Saqib, A., Tabbssum, M. R., Rashid, U., Ibrahim, M., Gill, S. S., and Mehmood, M. A. (2013). Marine macroalgae Ulva: a potential feed-stock for bioethanol and biogas production. Asian J. Agri. Biol. 1, 155-163.

Schenk, P., Thomas-Hall, S., Stephens, E., Marx, U., Mussgnug, J., Posten, C., et al. (2008). Second generation biofuels: high efficiency microalgae for biodiesel production. Bioenergy Res. 1, 20-43. doi:10.1007/s12155-008-9008-8

Schneider, R. C. S., Bjerk, T. R., Gressler, P. D., Souza, M. P., Corbelline, V. A., and Lobo, E. A. (2013). "Potential production of biofuel from microalgae biomass produced in wastewater," in Biodiesel - Feedstocks, Production and Applications, ed. Z. Fang (Rijeka: InTech). doi:10.5772/52439

Shaishav, S., Singh, R. N., and Satyendra, T. (2013). Biohydrogen from algae: fuel of the future. Int. Res. J. Env. Sci. 2, 44-47.

Shalaby, E. A. (2011). "Algal biomass and biodiesel production," in Biodiesel - Feedstocks and Processing Technologies, ed. S. Margarita (Rijeka: InTech), 111-132. ISBN: 978-953-307-713-0.

Sharma, R., Chisti, Y., and Banerjee, U. C. (2001). Production, purification, characterization, and applications of lipases. Biotechnol. Adv. 19, 627-662. doi:10.1016/ S0734-9750(01)00086-6

Sharma, Y. C., and Singh, B. (2009). Development of biodiesel: current scenario. Renew. Sustain. Energ. Rev. 13, 1646-1651. doi:10.1016/j.biortech.2010.06.057

Shi, X., Jung, K. W., Kim, H., Ahn, Y. T., and Shin, H. S. (2011). Direct fermentation of Laminaria japonica for biohydrogen production by anaerobic mixed cultures. Int. J. Hydrogen Energy 36, 5857-5864. doi:10.1016/j.ijhydene.2011.01.125

Shuping, Z., Yulong, W., Mingde, Y., Kaleem, I., Chun, L., and Tong, J. (2010). Production and characterization of bio-oil from hydrothermal liquefaction of microalgae Dunaliella tertiolecta cake. Energy 35, 5406-5411. doi:10.1016/j.energy.2010. 07.013

Singh, A., He, B., Thompson, J., and Gerpen, J. V. (2006). Process optimization of biodiesel production using alkaline catalysts. Appl. Eng. Agric. 22, 597-600. doi:10.13031/2013.21213

Singh, A., Nigam, P. S., and Murphy, J. D. (2011). Mechanism and challenges in commercialisation of algal biofuels. Bioresour. Technol. 102, 26-34. doi:10.1016/ j.biortech.2010.06.057

Singh, D. P., and Trivedi, R. K. (2013). Production of biofuel from algae: an economic and eco-friendly resource. Int. J. Sci. Res. 2, 352-357.

Singh, J., and Gu, S. (2010). Commercialization potential of microalgae for biofuels production. Renew. Sustain. Energ. Rev. 14, 2596-2610. doi:10.1016/j.rser.2010. 06.014

Singh, R., Behera, S., Yadav, Y. K., and Kumar, S. (2014). "Potential of wheat straw for biogas production using thermophiles," in Recent Advances in Bio-Energy Research, eds S. Kumar, A. K. Sarma, S. K. Tyagi, and Y. K. Yadav (Kapurthala: SSS-National Institute of Renewable Energy), 242-249.

Spolaore, P., Joannis-Cassan, C., Duran, E., and Isambert, A. (2006). Commercial applications of microalgae. J. Biosci. Bioeng. 101, 87-96. doi:10.1263/jbb.101.87

Stergiou, P. Y., Foukis, A., Filippou, M., Koukouritaki, M., Parapouli, M., Theodorou, L. G., et al. (2013). Advances in lipase-catalyzed esterification reactions. Biotechnol. Adv. 31, 1846-1859. doi:10.1016/j.biotechadv.2013.08.006

Sukumaran, R. K., Singhania, R., Mathew, G. M., and Pandey, A. (2008). Cellulase production using biomass feed stock and its application in lignocellulose saccharification for bio-ethanol production. Renew. Energ. 34, 421-424. doi:10.1016/j.renene.2008.05.008
Surendhiran, D., and Vijay, M. (2012). Microalgal biodiesel-acomprehensive review on the potential and alternative biofuel. Res. J. Chem. Sci. 2, 71-82.

Susilaningsih, D., Djohan, A. C., Widyaningrum, D. N., and Anam, K. (2009). Biodiesel from indigenous Indonesian marine microalgae Nanochloropsis sp. J. Biotechnol. Res. Trop. Reg. 2, 1-4.

Tamer, E., Amin, M. A., Ossama, E. T., Bo, M., and Benoit, G. (2006). Biological treatment of industrial wastes in a photobioreactor. Water Sci. Technol. 53, 117-125. doi:10.2166/wst.2006.344

Thomas, D. N. (2002). Seaweeds. Washington, DC: Smithsonian Books, Natural History Museum.

Topare, N., Rout, S. J., Renge, V. C., Khedkar, S. V., Chavan, Y. P., and Bhagat, S. L. (2011). Extraction of oil from algae by solvent extraction and oil expeller method. Int. J. Chem. 9, 1746-1750.

Trivedi, N., Gupta, V., Reddy, C. R., and Jha, B. (2013). Enzymatic hydrolysis and production of bioethanol from common macrophytic green alga Ulva fasciata Delile. Bioresour. Technol. 150, 106-112. doi:10.1016/j.biortech. 2013.09.103

Vanegas, C. H., and Bartlett, J. (2013). Green energy from marine algae: biogas production and composition from the anaerobic digestion of Irish seaweed species. Environ. Technol. 34, 2277-2283. doi:10.1080/09593330.2013.765922

Vergara-Fernandez, A., Vargas, G., Alarcon, N., and Velasco, A. (2008). Evaluation of marine algae as a source of biogas in a two-stage anaerobic reactor system. Biomass Bioenergy 32, 338-344. doi:10.1016/j.biombioe.2007.10.005

Wargacki, A. J., Leonard, E., Win, M. N., Regitsky, D. D., Santos, C. N., Kim, P. B., et al. (2012). An engineered microbial platform for direct biofuel production from brown macroalgae. Science 335, 308-313. doi:10.1126/science.1214547

Wecker, M. S. A., Meuser, J. E., Posewitz, M. C., and Ghirardi, M. L. (2011). Design of a new biosensor for algal $\mathrm{H}_{2}$ production based on the $\mathrm{H}_{2}$-sensing system of Rhodobacter capsulatus. Int. J. Hydrogen Energy 36, 11229-11237. doi:10.1016/j.ijhydene.2011.05.121

Widjaja, A., Chien, C. C., and Ju, Y. H. (2009). Study of increasing lipid production from fresh water microalgae Chlorella vulgaris. J. Taiwan Inst. Chem. Eng. 40, 13-20. doi:10.1016/j.jtice.2008.07.007

Williams, P. J. L. B., and Laurens, L. M. L. (2010). Microalgae as biodiesel and biomass feedstocks: review and analysis of the biochemistry, energetics and economics. Energy Environ. Sci 3, 554-590. doi:10.1039/b924978h

Wu, X., Li, Q., Dieudonne, M., Cong, Y., Zhou, J., and Long, M. (2010). Enhanced $\mathrm{H}_{2}$ gas production from bagasse using adhE inactivated Klebsiella oxytoca HP1 by sequential dark-photo fermentations. Bioresour. Technol. 101, 9605-9611. doi:10.1016/j.biortech.2010.07.095

Yacoby, I., Pochekailov, S., Topotrik, H., Ghirardi, M. L., King, P. W., and Zhang, S. (2011). Photosynthetic electron partitioning between ( $\mathrm{FeFe}$ )-hydrogenase and ferrodoxin: NADP+-oxidoreductase (FNR) enzymes in vitro. Proc. Natl. Acad. Sci. U.S.A. 108, 9396-9401. doi:10.1073/pnas.1103659108

Yanagisawa, M., Nakamura, K., Ariga, O., and Nakasaki, K. (2011). Production of high concentrations of bioethanol from seaweeds that contain easily hydrolysable polysaccharides. Process Biochem. 46, 2111-2116. doi:10.4161/bioe.23396

Yanqun, L., Mark, H., Nan, W., Christopher, Q. L., and Nathalie, D. C. (2008). Biofuels from microalgae. Biotechnol. Progress. 24, 815-820.

Yazdani, P., Karimi, K., and Taherzadeh, M. J. (2011). "Improvement of enzymatic hydrolysis of a marine macro-alga by dilute acid hydrolysis pretreatment," in World Renewable Energy Congress (Bioenergy Technology), 8-13 May, ed. B. Moshfegh (Linkoping, Sweden), 186-191.

Yen, H. W., and Brune, D. E. (2007). Anaerobic co-digestion of algal sludge and waste paper to produce methane. Bioresour. Technol. 98, 130-134. doi:10.1016/j. biortech.2005.11.010

Yoon, J. J., Kim, Y. J., Kim, S. H., Ryu, H. J., Choi, J. Y., Kim, G. S., et al. (2010). Production of polysaccharides and corresponding sugars from red seaweed. $A d v$ Mater. Res. 9, 463-466. doi:10.1016/j.biortech.2008.11.053

Yoon, M., Choi, J. I., Lee, J. W., and Park, D. H. (2012). Improvement of saccharification process for bioethanol production from Undaria sp. by gamma irradiation. Radiat. Phys. Chem. 81, 999-1002. doi:10.1016/j.radphyschem.2011. 11.035

Yuan, H. (2014). Effect of ammoniation pretreatment at low moisture content on anaerobic digestion performance of rice straw. Bioresources 9, 6707-6718. doi:10.15376/biores.9.4

Yuan, X., Shi, X., Zhang, D., Qiu, Y., Guo, R., and Wang, L. (2011). Biogas production and microcystin biodegradation in anaerobic digestion of blue algae. Energy Environ. Sci. 4, 1511-1515. doi:10.1039/c0ee00452a 
Zhang, C. (2013). Alkaline pretreatment for enhancement of biogas production. Bioresour. Technol. 149, 353-358. doi:10.1016/j.biortech.2013.09.070

Zheng, Y. (2009). Anaerobic digestion of saline creeping wild ryegrass for biogas production and pretreatment of particleboard material. Bioresour. Technol. 100, 1582-1588. doi:10.1016/j.biortech.2008.08.048

Zhong, W., Zhang, Z., Luo, Y., Qiao, W., Xiao, M., and Zhang, M. (2012). Biogas productivity by co-digesting Taihu blue algae with corn straw as an external carbon source. Bioresour. Technol. 114, 181-186. doi:10.1016/j.biortech.2012.02.111

Conflict of Interest Statement: The authors declare that the research was conducted in the absence of any commercial or financial relationships that could be construed as a potential conflict of interest.
Received: 31 July 2014; accepted: 29 December 2014; published online: 11 February 2015.

Citation: Behera S, Singh R, Arora R, Sharma NK, Shukla M and Kumar S (2015) Scope of algae as third generation biofuels. Front. Bioeng. Biotechnol. 2:90. doi: 10.3389/fbioe.2014.00090

This article was submitted to Marine Biotechnology, a section of the journal Frontiers in Bioengineering and Biotechnology.

Copyright $\odot 2015$ Behera, Singh, Arora, Sharma, Shukla and Kumar. This is an openaccess article distributed under the terms of the Creative Commons Attribution License (CC BY). The use, distribution or reproduction in other forums is permitted, provided the original author(s) or licensor are credited and that the original publication in this journal is cited, in accordance with accepted academic practice. No use, distribution or reproduction is permitted which does not comply with these terms. 